\title{
Long-term persistence and effects of fetal microchimerisms on disease onset and status in a cohort of women with rheumatoid arthritis and systemic lupus erythematosus
}

\author{
Marianne Kekow ${ }^{1 *}$, Maria Barleben ${ }^{1}$, Susanne Drynda², Sibylle Jakubiczka ${ }^{3}$, Jörn Kekow ${ }^{2}$ and Thomas Brune ${ }^{1}$
}

\begin{abstract}
Background: The discovery of a fetal cells transfer to the mother is a phenomenon with multiple implications for autoimmunity and tolerance. The prevalence and meaning of the feto-maternal microchimerism (MC) in rheumatic diseases has not been thoroughly investigated. The aim of this study was to analyze the prevalence of fetal MC in patients with inflammatory rheumatic diseases and to investigate the association of $M C$ with disease onset and current status.

Methods: A total of 142 women who gave birth to at least one male offspring were recruited: 72 women with rheumatoid arthritis (RA), 16 women with systemic lupus erythematosus (SLE), and 54 healthy women. For the detection of fetal microchimerism a nested PCR method was used to amplify a Y chromosome specific sequence (TSPY1). For characterization of disease activity we analyzed autoantibody profiles and X-rays in RA, and in addition complement levels in SLE respectively.

Results: A significant higher prevalence of fetal MC was found in RA (18\%) and SLE (31\%) compared to controls (3.7\%) ( $p=0.02$ and $p=0.006$, resp.). The mean age at disease onset was comparable in $M C+$ and $M C$ - RA patients. Disease onset occurred $18.7(M C+)$ and 19.8 (MC-) years post partum of the first son, respectively. The presence of anti-CCP and RF did not differ significantly, anti-CCP were found in 75\% of MC + and 87\% of MC- patients, RF in $75 \%$ of both $M C+$ and $M C$ - patients. A slightly higher mean Steinbrocker score in $M C+$ patients was associated with longer disease duration in MC + compared to MC- RA. In SLE patients the mean age at disease onset was 42.6 years in MC + and 49.1 years in MC- patients. Disease onset occurred 24.0 and 26.4 years post partum of the first son for $M C+$ and MC- patients, respectively. The presence of ANA and anti-dsDNA antibodies, C3, C4 and CH50 did not differ significantly. Conclusion: Our results indicate a higher frequency of long-term male MC in RA and SLE patients compared with controls without impact on disease onset and status in RA and SLE.
\end{abstract}

Keywords: Microchimerism, RA, SLE, Pregnancy

\section{Background}

Rheumatoid arthritis (RA) and systemic lupus erythematosus (SLE) are autoimmune diseases with a higher prevalence in women than in men (3:1 women vs. men in RA and 9:1 in SLE, respectively) [1]. The cause and onset of the diseases still remain unclear. RA and SLE are, once established, highly affected by pregnancy. Guthrie et al.

\footnotetext{
* Correspondence: m_kekow@hotmail.com

'Children's Hospital, University of Magdeburg, Leipziger Str. 44, Magdeburg 39120, Germany

Full list of author information is available at the end of the article
}

reported protective effects of pregnancy for the development of RA in women [2]. In this study the risk of developing RA increased with the number of years after the birth of the youngest child. These findings, together with the first description of fetal DNA in pregnant women $[3,4]$ gave raise to the question of the role of this chimerism for the development of autoimmune diseases. The presence of very small amounts of cells or DNA is now called microchimerism (MC), e.g. detectable by PCR $[5,6]$. Recently the fetal DNA became a focus of interest as a non invasive diagnostic tool for 
chromosomal abnormalities such as Down`s syndrome in pregnant women $[7,8]$.

In autoimmune diseases the frequency of $\mathrm{MC}$ differs but studies indicate that the frequency of $\mathrm{MC}$ is higher in women with some autoimmune diseases than in healthy women [6]. In the field of rheumatic diseases patients with scleroderma, RA, SLE und Sjögren's syndrome have been investigated [9-16]. However, data are inconsistent due to small numbers of patients, different methodology, and patient selection.

Prevalence studies in healthy women by our group found the TSPY1 gene as MC indicator present in about $70 \%$ of the women at delivery declining to $4 \%$ after a 4 year follow up [17]. This is quite comparable with other reports $[13,18-20]$. For the present study we could apply the detection of a TSPY1 gene sequence on the Y chromosome in patients even decades after delivery.

The aim of our study was to evaluate the frequency of microchimerism in RA and SLE patients and to investigate the effects of fetal microchimerisms on disease onset and status. The detection of fetal MC was performed by nested PCR. Other sources for male DNA were strictly excluded by questionnaire. Different clinical measures, $\mathrm{X}$-ray and laboratory parameters were collected from the patient's records. The comparison of MC positive and MC negative RA and SLE patients with healthy controls revealed a long persistence of $\mathrm{MC}$.

\section{Methods}

\section{Patients}

All together 142 female subjects were studied: 72 patients with RA, 16 patients with SLE and 54 healthy controls. All subjects were selected based on the following criteria: $(a)$ a previous pregnancy with at least one male offspring, (b) no history of abortion, and $(c)$ no history of blood transfusions. The patients had to meet the American College of Rheumatology criteria for RA and SLE respectively [21,22]. Clinical data on the patients with RA and SLE were collected from their medical records including their X-rays, and laboratory results. Special family history was obtained by questionnaires. The subjects were outpatients in one rheumatology centre (Clinic of Rheumatology, University of Magdeburg).

The study was approved by the local human subjects committee of the University of Magdeburg (approval number 133/04), and all patients were asked for written consent.

For RA patients, the following data were collected: rheumatoid factor (RF); anti-cyclic citrullinated peptide antibodies (anti-CCP); and structural damage as defined by the Steinbrocker score for X-rays of hand and feet $[23,24]$. All X-rays were blinded and red separately by two rheumatologists. RF and anti-CCP were determined by commercial assays (ABX Pentra RF CP, HORIBA,
Germany; and anti-CCP-ELISA, A.Menarini Diagnostics, Italy, respectively).

In SLE patients, the antinuclear antibodies (ANA), the dsDNA antibodies (dsDNA Ab), serum C3, C4, and CH50 were analyzed. ANA testing was performed by indirect immune fluorescence, and the determination of dsDNA Ab by ELISA (all Euroimmun AG, Germany). Determination of complement factors $\mathrm{C} 3, \mathrm{C} 4$ and $\mathrm{CH} 50$ was run using a turbidimetric method with assays from Biokit, Spain (C3, C4), and Wako Chemicals, Germany (CH50).

\section{Sample preparation and nested PCR}

Genomic DNA from peripheral blood was extracted using the QIAamp DNA Blood Midi Kit (QIAGEN, Germany) according to the manufacturer's instructions. Blood samples from a male subject and a nullipara woman were used as positive and negative controls.

A sequence in the TSPY gene located on the short arm of the Y-chromosome (encoding the testis specific protein Y-linked 1, and also known as CT78 and DYS14) was detected by amplifying genomic DNA in a nested polymerase chain reaction (PCR). Primers were designed based on a sequence described by Arnemann et al. [25]. The following primer pairs were used for the first and second PCR reactions: first PCR: forward: $5^{\prime}$ - ATG CGG CAG AGA AAC CCT TG - 3'; reverse: 5'- TAA GGC CTC CTG TGT TCA CG - $3^{\prime}$ and second PCR: forward: 5' - CAG AAG CGA GTT CAG AGC AG - 3'; reverse: 5'- TTC TGA GGC TGA CTG CAC TG - 3'.

The first PCR reaction was performed in a total volume of $50 \mu \mathrm{l}$ and contained $5 \mu \mathrm{l}$ genomic DNA at a concentration of $80-100 \mu \mathrm{g} / \mathrm{ml}, 5 \mu \mathrm{l} 10$ fold Taq polymerase buffer, $\mathrm{MgCl}_{2}$ at a final concentration of $50 \mathrm{mM}, 20$ pmol of each primer, $4 \mu \mathrm{l}$ of the dNTP mix (2 mM total) and 1.5 units of Taq DNA polymerase (Invitrogen, USA). PCR conditions were as follows; initial denaturation at $94^{\circ} \mathrm{C}$ for 5 minutes, 35 cycles at $94^{\circ} \mathrm{C}$ for 60 seconds; $63^{\circ} \mathrm{C}$ for 60 seconds; and $72^{\circ} \mathrm{C}$ for 60 seconds; and a final extension at $72^{\circ} \mathrm{C}$ for 10 minutes. Two $\mu \mathrm{l}$ of the reaction mixture of the first reaction containing the $278 \mathrm{bp}$ amplificate were used as template in the second PCR reaction in a total volume of $20 \mu \mathrm{l}$. The second primer pair was used, beyond that the composition of the reaction mixture was identical to the first reaction. The PCR conditions were also similar to the first reaction, but only 25 cycles were run. The PCR products were separated on a $2 \%$ agarose gel in 1fold TRIS borate-EDTA buffer. For sizing the 186 bp product a 100 bp ladder was used.

Each PCR amplification step included a positive control (DNA from a male donor, diluted 1:20,000 in water for molecular biology), and a negative control (DNA-free water) to detect PCR contamination. All samples were tested twice. 
The PCR was optimized to detect male-specific DNA sequences in DNA preparations from a mixture of blood from a male and a female donor at a ratio of 1:40,000. A reliable detection of male blood in female blood, male DNA in female DNA and male DNA in Tris-EDTA buffer with a mixture ratio of 1: 40,000 was possible with the optimized PCR.

\section{Data processing and analysis}

For analysis, the software package SPSS was used (V 18.0). Data are presented as mean, standard error of the mean (SEM), min-max, and the 95\% confidence interval. The t-test was used to determine the significance of differences between the means of independent samples. Differences in frequencies were analysed by applying the Fisher's exact test.

\section{Results}

The overall prevalence of fetal MC was $18.1 \%$ in RA patients (mean 37.3 years after the birth of the last son) and $31.3 \%$ in patients with SLE (mean 29.8 years after the birth of the last son) which is significantly higher as compared to $3.7 \%$ in healthy controls $(\mathrm{HC})(\mathrm{p}=0.023$ and $\mathrm{p}=0.006$, resp.) (Table 1 ).

In healthy controls, the mean age at the birth of the first son was 25.9 years which is comparable to the RA and SLE patients. None of our patients or controls had disabled children.

\section{Rheumatoid arthritis patients}

In RA patients the disease onset was 18.7 and 19.8 years post partum of the first son for $\mathrm{MC}+$ and $\mathrm{MC}$ - patients, respectively (Table 2). Patients with two or more sons had a higher frequency of MC than patients with only one son without reaching statistical significance $(p=0.218)$ (Table 3). The presence and the levels of anti-CCP and RF did not differ significantly: anti-CCP were found in $75 \%$ of $\mathrm{MC}+$ and $87 \%$ of $\mathrm{MC}-\mathrm{RA}$ patients; RF in $75 \%$ of both $\mathrm{MC}+$ and $\mathrm{MC}$ - patients (Table 2).

A slightly higher Steinbrocker score in $\mathrm{MC}+$ patients (3.2 vs. 3.0) was associated with longer disease duration of about 23 years in $\mathrm{MC}+\mathrm{RA}$ and 18 years in MC- RA with no evidence for structural damage due to $\mathrm{MC}$ positivity (Table 2).

The frequency of biological therapies, mostly TNF blocking agents, was comparable in both groups (Table 2). More

Table 1 Overall prevalence of fetal MC $(\mathrm{HC}=$ healthy controls)

\begin{tabular}{llll}
\hline & RA $^{1}$ & SLE $^{2,3}$ & HC \\
\hline MC + & $13(18.1 \%)$ & $5(31.3 \%)$ & $2(3.7 \%)$ \\
$M C-$ & $59(81.9 \%)$ & $11(68.7 \%)$ & $52(96.3 \%)$ \\
\hline
\end{tabular}

${ }^{1}$ RA vs. HC: $p=0.023,{ }^{2}$ SLE vs. HC: $p=0.006,{ }^{3}$ RA vs. SLE: $p=0.303$. than $80 \%$ of the patients received methotrexate at a dosage of 15 to $25 \mathrm{mg} /$ week, and took steroids up to $7.5 \mathrm{mg}$ per day. Due to the limited number of patients, conclusions may be difficult.

\section{Systemic lupus erythematosus patients}

In SLE, the mean age at disease onset was 42.6 years in $\mathrm{MC}+$ and 49.1 years in MC- patients. Disease onset occurred 24.0 and 26.4 years post partum of the first son for $\mathrm{MC}+$ and $\mathrm{MC}$ - patients, respectively (Table 4). Thirteen out of 16 patients with SLE (81\%) have given birth to only one son. $40 \%$ of $\mathrm{MC}+$ patients have more than one son compared to only $9 \%$ of MC-patients (Table 3 ). The presence of ANA and dsDNA antibodies, and the lab test results including $\mathrm{C} 3, \mathrm{C} 4$ and $\mathrm{CH} 50$ did not differ significantly (Table 4). In MC + patients sicca symptoms were found most frequently (80\%) followed by arthritis (60\%), central nervous system abnormalities (20\%) and kidney involvement (20\%). In contrast, in MC- patients joints were affected in $70 \%$ of the cases followed by skin $(60 \%)$, central nervous system (30\%) and sicca symptoms $(20 \%)$.

\section{Discussion}

Microchimerisms have been investigated for more than 30 years with different methods. With sensitive techniques such as PCR even very small amounts of male DNA can be detected in the female organism [26-28]. In the present study, patients with RA and SLE were tested for the occurrence of the TSPY1 gene in the peripheral blood. The share of women with MC in RA patients was significantly increased compared to the control group. The prevalence of a MC in SLE patients was also significantly increased compared to the control group. Compared with the RA group, the prevalence is increased in the SLE group, but does not achieve statistical significance, which may be due to the limited number of patients.

A comparison of our data on the prevalence of $\mathrm{MC}$ with other reports has limitations. The detection methods used in each study and the experimental setting differ notably (Table 5) [14,29-37]. In addition, different inclusion and exclusion criteria (especially the inclusion of blood transfusions or abortions) can affect the frequency of detected MC. Depending on methods and patients selected, the prevalence of MC in RA patients can be found between $18 \%$ (Yan et al.) and 42\% (Rak et al.) [14,30]. The study of Yan et al. compared the frequency of $\mathrm{MC}$ in 71 patients with RA and 49 healthy controls without analyzing the severity of disease or duration of disease. Women with a history of abortion were not excluded from the study. In healthy individuals they found a slightly elevated frequency of MC (24\%) compared to RA patients (18\%) [31]. Studying 25 pregnant RA patients the same group reported a correlation of RA disease activity and fetal DNA 
Table 2 Patient characteristics of MC + and MC- RA patients at study entry

\begin{tabular}{|c|c|c|c|}
\hline & $\mathrm{MC}+\mathrm{RA}$ & MC- RA & all RA \\
\hline Mean age at study entry (SEM) & $66.0^{*}(2.5)$ & $61.2^{*}(1.4)$ & $61.7(1.3)$ \\
\hline $\min -\max$ & $48-76$ & $41-84$ & $41-84$ \\
\hline $95 \% \mathrm{Cl}$ of SEM & $58.6 / 68.5$ & $58.3 / 64.1$ & $59.2 / 64.3$ \\
\hline Mean age at disease onset (SEM) & $43.3^{*}(3.2)$ & $43.3^{*}(1.7)$ & $43.3(1.5)$ \\
\hline $\min -\max$ & $24-59$ & $18-72$ & $18-72$ \\
\hline $95 \% \mathrm{Cl}$ of SEM & $36.1 / 50.4$ & $40.0 / 46.7$ & $40.4 / 50.4$ \\
\hline Mean duration (years) between birth of first son and disease onset (SEM) & $18.7^{*}(2.9)$ & $19.8^{*}(1.5)$ & $19.6(1.3)$ \\
\hline $\min -\max$ & $0-29$ & $0-37$ & $0-37$ \\
\hline $95 \% \mathrm{Cl}$ of SEM & $12.3 / 25.5$ & $17.0 / 22.8$ & $12.3 / 25.5$ \\
\hline Mean age at birth of first son (SEM) & $25.4^{*}(1.5)$ & $23.4^{*}(0.6)$ & $23.7(0.6)$ \\
\hline $\min -\max$ & $20-35$ & $18-38$ & $18-38$ \\
\hline $95 \% \mathrm{Cl}$ of SEM & $22.0 / 28.8$ & 22.9/24.6 & $22.0 / 28.8$ \\
\hline CCP-antibody level & $\mathrm{n}=$ & $\mathbf{n}=$ & $\mathbf{n}=$ \\
\hline 0-25 IU/ml (negative) & $3(25 \%)$ & $7(13 \%)$ & $10(15 \%)$ \\
\hline 26-100 IU/ml (positive) & $1(8 \%)$ & $9(17 \%)$ & $10(15 \%)$ \\
\hline 101-1000 IU/ml (positive) & $5(42 \%)$ & $23(43 \%)$ & $28(42 \%)$ \\
\hline$>1000$ IU/ml (positive) & $3(25 \%)$ & $15(28 \%)$ & $18(27 \%)$ \\
\hline Total CCP-antibody positive & $9 *(75 \%)$ & $47^{*}(87 \%)$ & $56(84 \%)$ \\
\hline RF level: 0-20 IU/ml (negative) & $3(25 \%)$ & $13(24 \%)$ & $16(24 \%)$ \\
\hline 21-100 IU/ml (positive) & $3(25 \%)$ & $31(56 \%)$ & $34(51 \%)$ \\
\hline$>100 \mathrm{IU} / \mathrm{ml}$ (positive) & $6(50 \%)$ & $11(20 \%)$ & $17(25 \%)$ \\
\hline Total RF positive & $9 *(75 \%)$ & $42^{*}(75 \%)$ & $51(75 \%)$ \\
\hline Patients treated with 'Biologicals' & $10(77 \%)^{*}$ & $40(68 \%)^{*}$ & $50(70 \%)$ \\
\hline Steinbrocker score 1 & $1(8 \%)$ & $6(10 \%)$ & $7(10 \%)$ \\
\hline 2 & $2(15 \%)$ & $11(22 \%)$ & $13(20 \%)$ \\
\hline 3 & $3(23 \%)$ & $16(30 \%)$ & $19(29 \%)$ \\
\hline 4 & $7(53 \%)$ & $22(37 \%)$ & $29(41 \%)$ \\
\hline Mean Steinbrocker score & $3.23^{*}$ & $3.04^{*}$ & 3.07 \\
\hline
\end{tabular}

${ }^{*} p(M C+v s . M C-)$ not statistically significant.

levels in pregnant women [30]. Rak et al. used the detection of fetal HLA-DRB1 sequences in the maternal blood for the detection of MC transmitted to the mother [14]. However, blood transfusions and early fetal loss were not excluded. They speculate that MC may contribute to the

\section{Table 3 Number of sons in RA and SLE patients}

\begin{tabular}{lll}
\hline & $\mathbf{1}$ son & $\mathbf{2}$ sons \\
\hline${ }^{1}$ RA patients MC+ & $7(63.6 \%)$ & $4(36.2 \%)$ \\
${ }^{1}$ RA patients MC- & $47(82.5 \%)$ & $10(17.5 \%)$ \\
Total RA patients & $54(79.4 \%)$ & $14(20.6 \%)$ \\
${ }^{2}$ SLE patients MC+ & $3(60 \%)$ & $2(40 \%)$ \\
${ }^{2}$ SLE patients MC- & $10(91 \%)$ & $1(9 \%)$ \\
Total SLE patients & $13(81 \%)$ & $3(19 \%)$ \\
\hline
\end{tabular}

${ }^{1}$ RA: number of sons $M C+v s$. MC-: $p=0.218$.

${ }^{2}$ SLE: number of sons MC + vs. MC-: $p=0.214$. risk of an autoimmune disease by providing susceptibility alleles. Using the disease activity score 28 (DAS28) no correlation with the presence of MC was found [14]. Time between the last pregnancy and the DNA testing was not provided making a direct comparison with our data difficult. Atkins et al. tested tissue from rheumatic nodules of 15 RA patients for male DNA using a PCR for the DYS14 sequence [32]. $74 \%$ of the removed rheumatic nodules from RA patients tested positive for male DNA. They found no association of $\mathrm{MC}$ and joint destruction [32]. Besides peripheral blood and nodules, other tissues were also investigated for MC. Hromadnikova et al. analyzed synovial tissue and skin samples of 19 RA patients for the SRY gene [34]. The patients had a mean age of 55.2 years and had given birth to at least one son. They compared the results to samples from RA patients without sons. The synovial tissue of 5 out of 13 women (38.5\%) and 4 
Table 4 Patient characteristics of MC + and MC- SLE patients at study entry

\begin{tabular}{|c|c|c|c|}
\hline & MC + SLE & MC- SLE & all SLE \\
\hline Mean age (SEM) & $51.2^{*}(3.4)$ & $57.1^{*}(3.7)$ & $55.2(2.7)$ \\
\hline $\min -\max$ & $42-58$ & $45-82$ & $42-82$ \\
\hline $95 \% \mathrm{Cl}$ of SEM & $41.6 / 60.8$ & $48.9 / 65.5$ & $49.8 / 60.7$ \\
\hline Mean age at disease onset (SEM) & $42.6 *(3.8)$ & $49.1^{*}(4.5)$ & $46.9(3.3)$ \\
\hline $\min -\max$ & $35-54$ & $27-75$ & $27-75$ \\
\hline $95 \% \mathrm{Cl}$ of SEM & $32.1 / 53.1$ & $39.0 / 59.2$ & $40.0 / 54.0$ \\
\hline Mean age at birth of first son (SEM) & $24.0^{*}(2.4)$ & $26.4^{*}(1.6)$ & $24.7(1.3)$ \\
\hline $\min -\max$ & $18-31$ & $22-38$ & $18-38$ \\
\hline $95 \% \mathrm{Cl}$ of SEM & $16.3 / 31.7$ & $22.7 / 30.1$ & $22.8 / 28.7$ \\
\hline ANA titer (Median) & $1: 640$ & $1: 640$ & $1: 640$ \\
\hline \multicolumn{4}{|l|}{$(n=10 M C-n=4 M C+)$} \\
\hline $\min -\max$ & $160-2560$ & $160-2560$ & $160-2560$ \\
\hline dsDNA-antibodies present & $0 / 3(0 \%)$ & $3 / 10(30 \%)$ & $3 / 13(23 \%)$ \\
\hline C3 $(g / l)$ Mean $(n=9 M C-, n=2 M C+)$ & 1.47 & 1.28 & 1.32 \\
\hline $\min -\max$ & $1.45-1.50$ & $0.94-1.55$ & $0.94-1.55$ \\
\hline$C 4(g / l)$ Mean $(n=9 M C-, n=2 M C+)$ & 0.28 & 0.23 & 0.24 \\
\hline $\min -\max$ & $0.22-0.35$ & $0.13-0.33$ & $0.13-0.35$ \\
\hline CH50 Mean (U/ml) & 56.8 & 51.4 & 52.3 \\
\hline$(n=9 M C-, n=2 M C+)$ min-max & $52.7-60.9$ & $42.1-59.1$ & $42.1-60.9$ \\
\hline
\end{tabular}

Normal ranges: C3 0.9-1.8 g/l; C4 0.1-0.4 g/l; CH50 23-46 U/ml; ANA: 1:80-1:320 (+ -++), 1:640-1:1280 (+++), >1:2560 (++++); dsDNA Ab: < 100 RE/ml; *p (MC+ vs. MC-) not statistically significant.

out of 10 skin samples contained male DNA. In samples from patients without male offspring, no male DNA was found [34].

In SLE patients, varying data for the prevalence of $\mathrm{MC}$ can be found as well. The frequencies range between $0 \%$ found by Miyashita and $50 \%$ as described by Mosca et al. [15,35]. The latter group analyzed blood samples from 22 SLE patients and 24 healthy controls for the Y chromosome using a nested PCR method with strict exclusion criteria. For both groups, in $50 \%$ of the blood samples MCs were detected which may be explained by a broad variation time between last pregnancy and the time point of DNA testing. They found no differences in ANA, dsDNA-Ab, and complement levels associated with or without MC [35].

Besides pregnancy, high rates of abortions in SLE may be a major source for feto-maternal MC. A meta-analysis of 11 studies by Khosrotehrani et al. could identify a higher rate of MC in patients with fetal loss, which was independent from the number of gestations [38]. Tissue was often subject for studies of MC in SLE [36,37]. MC was found in different tissues including kidney, intestine or lung [33].

In our study, patients who had received blood transfusions were excluded. This is because the kinetic of the removal of foreign cells and DNA is not yet fully understood [39]. In addition, it is unknown whether the blood transfusion is from a male or female donor. Even if the average percentage of male blood donors is known, it is difficult to calculate its influence on the prevalence of MC. By excluding RA and SLE patients with blood transfusions in the past more than $50 \%$ of the potential candidates for our study were excluded. A reason for this high number could be a higher frequency in joint replacement surgery, cardiovascular diseases, and anemia by the disease itself or due to side effects of drugs. Many of the investigated patients reported blood transfers in conjunction with gynecological surgery.

Another issue which has to be taken into account is that all of our RA and SLE patients were treated with anti-inflammatory and immune modulating medication. The treatment reduces the progression of the disease and decreases differences between treated and non-treated patients. For selecting RA patients, we used a large local database including many patients receiving biological therapies. Active treatment may have influence on the progression including structural damage and laboratory parameters but this may also have impact on the clearance of fetal components. For RA we chose two serological parameters which are associated with a high disease burden and a poor prognosis (RF and anti-CCP). Both antibodies were found to be positive in a high number of patients, and the absolute values indicate a more severe disease. This is also reflected 
Table 5 Overview of major MC studies in RA and SLE patients

\begin{tabular}{|c|c|c|c|c|c|c|}
\hline Disease & $\begin{array}{l}\text { Number of subjects/ } \\
\text { samples }\end{array}$ & $\begin{array}{l}\text { Method/ } \\
\text { Material }\end{array}$ & MC positive & $\begin{array}{l}\text { Mean disease duration } \\
\text { (years)/age of subjects } \\
\text { (years) }\end{array}$ & $\begin{array}{l}\text { History of blood } \\
\text { transfusion }\end{array}$ & References \\
\hline$\overline{\mathrm{RA}}$ & $71 \mathrm{RA} ; 49 \mathrm{HC}$ & PCR/ PBMC & $18 \%$ RA, $24 \% \mathrm{HC}$ & n.r. / 33 (median) & n.r. & Yan et al. [31] \\
\hline \multirow[t]{2}{*}{$R A$, JIA } & 25 pregnant patients: & PCR/ PBMC & & n.r. / 33 & n.r. & Yan at al. [30] \\
\hline & $\begin{array}{l}\text { (21 with improvement } \\
\text { of arthritis, } 4 \text { with } \\
\text { active arthritis) }\end{array}$ & & $\begin{array}{l}100 \% \\
50 \%\end{array}$ & & & \\
\hline \multirow[t]{4}{*}{ RA } & DRB1*01 MC: & PCR/PBMC & DRB1*01 MC: & n.r./ 57 (RA); & included & Rak et al. [14] \\
\hline & $33 \mathrm{RA}, 46 \mathrm{HC}$ & & RA: $30 \%, H C: 4 \%$ & $52(\mathrm{HC})$ & $(17 \%, \mathrm{HC} 13 \%)$ & \\
\hline & DRB1*04 MC: & & RA: $40 \%$, & & & \\
\hline & $48 \mathrm{RA}, 64 \mathrm{HC}$ & & RA: $40 \%, H C: 8 \%$ & & & \\
\hline RA & $\begin{array}{l}15 \text { patients } / 19 \\
\text { granulomatous } \\
\text { nodules }\end{array}$ & PCR/ tissue & $\begin{array}{l}\text { 13/15 patients, } \\
14 / 19 \text { nodules }\end{array}$ & $22.5 / 66$ & included & Atkins et al. [32] \\
\hline \multirow[t]{4}{*}{ RA } & QKRAA MC: & $\mathrm{PCR} / \mathrm{PBMC}$ & QKRAA MC & n.r. / 51 (RA), & n.r. & Yan et al. [29] \\
\hline & $52 \mathrm{RA}, 34 \mathrm{HC}$ & & RA: $17 \%, \mathrm{HC}: 3 \%$ & $42(\mathrm{HC})$ & & \\
\hline & QRRAA MC: & & QRRAA MC: & & & \\
\hline & $52 \mathrm{RA}, 34 \mathrm{HC}$ & & RA: $40 \%$, HC: $18 \%$ & & & \\
\hline \multirow[t]{2}{*}{ RA } & \multirow{2}{*}{$\begin{array}{l}13 \text { patients (synovial } \\
\text { tissue), } 10 \text { patients } \\
\text { (skin fibroblasts) }\end{array}$} & \multirow[t]{2}{*}{ PCR/tissue } & $38 \%$ & \multirow[t]{2}{*}{$16.4 / 55.5$} & \multirow[t]{2}{*}{ n.r. } & \multirow{2}{*}{$\begin{array}{l}\text { Hromadnikova } \\
\text { et al. [34] }\end{array}$} \\
\hline & & & $40 \%$ & & & \\
\hline SLE & $\begin{array}{l}1 \text { patient, } 44 \text { samples, } \\
11 \text { female control } \\
\text { subjects }\end{array}$ & FISH/tissue & $\begin{array}{l}\text { 100\% abnormal tissue, } \\
0 \% \text { normal tissue; } \\
0 / 11 \text { controls }\end{array}$ & $1 / 33$ & n.r. & Johnson et al. [33] \\
\hline SLE & 22 patients, $24 \mathrm{HC}$ & $\begin{array}{l}\text { PCR/whole } \\
\text { blood }\end{array}$ & SLE: $50 \%$ HC: $50 \%$ & $\begin{array}{l}\text { n.r. /44 (SLE), } \\
48(\mathrm{HC})\end{array}$ & excluded & Mosca et al. [35] \\
\hline SLE & $\begin{array}{l}49 \text { patients ( } 57 \text { renal } \\
\text { biopsies), } 51 \mathrm{HC} \\
\text { samples }\end{array}$ & FISH/tissue & $\begin{array}{l}\text { SLE: } 55 \% \text { of patients, } \\
51 \% \text { of samples HC: } \\
25 \% \text { of samples }\end{array}$ & n.r. / 31 (SLE) & included (31\%) & $\begin{array}{l}\text { Kremer Hovinga } \\
\text { et al. [37] }\end{array}$ \\
\hline SLE & $\begin{array}{l}7 \text { patients (48 organ } \\
\text { samples), } 34 \mathrm{HC} \\
\text { (146 samples) }\end{array}$ & FISH/tissue & $\begin{array}{l}\text { SLE: } 100 \% \text { ( } 50 \% \text { of } \\
\text { samples), HC: } 44 \% \text {, } \\
\text { (14\% of samples) }\end{array}$ & 7 /41 (SLE); $47(\mathrm{HC})$ & excluded & $\begin{array}{l}\text { Kremer Hovinga } \\
\text { et al. [36] }\end{array}$ \\
\hline
\end{tabular}

n.r.: not reported, FISH: fluorescent in situ hybridization. HC: healthy controls.

by the X-ray readings and the high percentage of biological treated patients. Further activity scores like the DAS28 were not applied since they may vary over time. Rak et al. could not find a correlation between the presence of MC and the DAS28 in a small cohort of eight women [14].

For SLE, we looked for single organ manifestations related to the disease. The obtained laboratory data indicate no active disease when the blood was taken for MC analysis. As mentioned before no relationship between the course of the disease and the presence of MC could be detected. Patients with an early stage of disease were not included in this study, so that it would need further investigations including patients with early stages of disease to show an influence of the MC on the disease onset. So far outliers in our study were not associated with MC.

Based on post mortem studies and animal experiments, Kremer Hovinga et al. discussed the role of a MC in patients with SLE in detail [40]. One hypothesis is that chimeric T-lymphocytes can provoke a graft-vs.host reaction; which means that by the recognition of host cells as foreign, activated chimeric T-helper lymphocytes may even stimulate the production of SLE specific antibodies. Another possible explanation is that the chimeric cell itself is the target of the host-vs.-graft reaction. Antigens present in maternal tissues will stimulate the immune system when the removal of chimeric antigens is poor, e.g. caused by impaired CD8 or natural killer cell function. As in our study, however, a relationship between the presence of chimerism and the clinical picture of the SLE is lacking. In a third hypothesis authors propose a healing effect of the progenitor chimeric cells replacing already damaged tissue. A consequence could be that the new tissue could induce a graft-vs.host reaction with further tissue damage. Reviewing the literature the authors also underline the difficulty of 
carrying out such studies in human SLE due to a high rate of unrecognized miscarriages leading to feto-maternal transfer of blood. In addition, animal studies are difficult to transfer into human.

\section{Conclusion}

In conclusion our data indicate a long persistence of MC as a potential marker of pathologic clearance of semiallogeneic DNA in rheumatic diseases without effects on disease onset and status. MC could be an epiphenomenon of autoimmunity and therapy without having an effect on the clinical manifestation and the phenotype of RA and SLE. Long-term randomized controlled trials, even together with the introduction of new DMARDs, would offer the possibility to detect the role of MC in autoimmune diseases in more detail.

\begin{abstract}
Abbreviations
ANA: Anti-nuclear antibody; CCP: Cyclic citrullinated peptide; FISH: Fluorescence in situ hybridization; HC: Healthy controls; JA: Juvenile idiopathic arthritis; MC: Microchimerism; PCR: Polymerase chain reaction; RA: Rheumatoid arthritis; SLE: Systemic lupus erythematosus; TE buffer: Tris-EDTA buffer; TSPY1: Testis specific protein Y-linked 1; yrs: Years.
\end{abstract}

\section{Competing interests}

The authors declare that they have no competing interests.

\section{Authors' contributions}

MK was involved in sample and data collection, carried out the genetic analysis and interpretation of data and drafted the manuscript. MK had full access to all of the data in the study and takes responsibility for the data and the accuracy of the data analysis. MB was involved in sample collection and preparation, and acquisition of data. SD contributed to patients' selection, data acquisition, interpretation and manuscript preparation. SJ contributed to the assay design. JK contributed to the concept and design of the study. TB conceived the study and was involved in developing the concept and design of the study and coordination. All authors substantially contributed to the study and approved the final manuscript.

\section{Acknowledgements}

We thank the staff of the Clinic of Rheumatology and the Children's Hospital, University of Magdeburg for helping us collecting the blood samples. We thank the Institute for Human Genetics, University of Magdeburg, for providing the laboratory facilities for performing the PCR.

\section{Author details}

${ }^{1}$ Children's Hospital, University of Magdeburg, Leipziger Str. 44, Magdeburg 39120, Germany. ${ }^{2}$ Clinic of Rheumatology, University of Magdeburg, Sophie-von-Boetticher-Strasse 1, Vogelsang, Gommern 39245, Germany. ${ }^{3}$ Institute of Human Genetics, University of Magdeburg, Leipziger Str. 44, Magdeburg 39120, Germany.

Received: 10 July 2013 Accepted: 31 October 2013 Published: 18 November 2013

\section{References}

1. Firestein G, Budd C, Harris E, Mclnnes I, Ruddy S, Sergent J: Kelly's textbook of rheumatology Vol.II. 8th edition. Philadelphia PA: Saunders Elsevier; 2008.

2. Guthrie KA, Dugowson CE, Voigt LF, Koepsell TD, Nelson JL: Does pregnancy provide vaccine-like protection against rheumatoid arthritis? Arthritis Rheum 2010, 62:1842-1848.

3. Bianchi DW: Circulating fetal DNA: its origin and diagnostic potential-a review. Placenta 2004, 25 Suppl A:S93-S101.

4. Lo YM, Corbetta N, Chamberlain PF, Rai V, Sargent IL, Redman CW, Wainscoat JS: Presence of fetal DNA in maternal plasma and serum. Lancet 1997, 350:485-487.
5. Evans PC, Lambert N, Maloney S, Furst DE, Moore JM, Nelson JL: Long-term fetal microchimerism in peripheral blood mononuclear cell subsets in healthy women and women with scleroderma. Blood 1999, 93:2033-2037.

6. Lambert N, Nelson JL: Microchimerism in autoimmune disease: more questions than answers? Autoimmun Rev 2003, 2:133-139.

7. Fan HC, Gu W, Wang J, Blumenfeld YJ, El-Sayed YY, Quake SR: Non-invasive prenatal measurement of the fetal genome. Nature 2012, 487:320-324.

8. Kitzman JO, Snyder MW, Ventura M, Lewis AP, Qiu R, Simmons LE, Gammill HS, Rubens CE, Santillan DA, Murray JC, Tabor HK, Bamshad MJ, Eichler EE, Shendure J: Noninvasive whole-genome sequencing of a human fetus. Sci Transl Med 2012, 4:1-18. 137ra76.

9. Nelson JL, Hughes KA, Smith AG, Nisperos BB, Branchaud AM, Hansen JA: Maternal-fetal disparity in HLA class II alloantigens and the pregnancyinduced amelioration of rheumatoid arthritis. N Engl J Med 1993, 329:466-471.

10. Nelson JL, Furst DE, Maloney S, Gooley T, Evans PC, Smith A, Bean MA, Ober C, Bianchi DW: Microchimerism and HLA-compatible relationships of pregnancy in scleroderma. Lancet 1998, 351:559-562.

11. Artlett CM, Welsh Kl, Black CM, Jimenez SA: Fetal-maternal HLA compatibility confers susceptibility to systemic sclerosis. Immunogenetics 1997, 47:17-22.

12. Artlett $C M$, Smith JB, Jimenez SA: Identification of fetal DNA and cells in skin lesions from women with systemic sclerosis. N Engl J Med 1998, 338:1186-1191.

13. Hamada $H$, Arinami $T$, Hamaguchi $H$, Kubo T: Fetal nucleated cells in maternal peripheral blood after delivery. Am J Obstet Gynecol 1994, 170:1 188-1193.

14. Rak JM, Maestroni L, Balandraud N, Guis S, Boudinet H, Guzian MC, Yan Z, Azzouz D, Auger I, Roudier C, Martin M, Didelot R, Roudier J, Lambert NC: Transfer of the shared epitope through microchimerism in women with rheumatoid arthritis. Arthritis Rheum 2009, 60:73-80.

15. Miyashita $\mathrm{Y}$, Ono $M$, Ono $M$, Ueki $H$, Kurasawa $K$ : $Y$ chromosome microchimerism in rheumatic autoimmune disease. Ann Rheum Dis 2000, 59:655-656.

16. Toda I, Kuwana M, Tsubota K, Kawakami Y: Lack of evidence for an increased microchimerism in the circulation of patients with Sjogren's syndrome. Ann Rheum Dis 2001, 60:248-253.

17. Barleben M: Kinetik des Auftretens fetaler DNA im mütterlichen Blut während und nach der Schwangerschaft. Germany: PhD thesis University of Magdeburg, Medical faculty; 2012

18. Bonney EA, Matzinger P: The maternal immune system's interaction with circulating fetal cells. J Immunol 1997, 158:40-47.

19. Hamada H, Arinami T, Kubo T, Hamaguchi H, Iwasaki H: Fetal nucleated cells in maternal peripheral blood: frequency and relationship to gestational age. Hum Genet 1993, 91:427-432.

20. Nguyen Huu S, Dubernard G, Aractingi S, Khosrotehrani K: Feto-maternal cell trafficking: a transfer of pregnancy associated progenitor cells. Stem Cell Rev 2006, 2:111-116.

21. Arnett FC, Edworthy SM, Bloch DA, McShane DJ, Fries JF, Cooper NS, Healey LA, Kaplan SR, Liang MH, Luthra HS: The American Rheumatism Association 1987 revised criteria for the classification of rheumatoid arthritis. Arthritis Rheum 1988, 31:315-324.

22. Petri M: Review of classification criteria for systemic lupus erythematosus. Rheum Dis Clin North Am 2005, 31:245-254.

23. Pincus T, Larsen A, Brooks RH, Kaye J, Nance EP, Callahan LF: Comparison of 3 quantitative measures of hand radiographs in patients with rheumatoid arthritis: Steinbrocker stage, Kaye modified Sharp score, and Larsen score. J Rheumatol 1997, 24:2106-2112.

24. Kaye JJ, Fuchs HA, Moseley JW, Nance EP Jr, Callahan LF, Pincus T: Problems with the Steinbrocker staging system for radiographic assessment of the rheumatoid hand and wrist. Invest Radiol 1990, 25:536-544.

25. Arnemann J, Epplen JT, Cooke HJ, Sauermann U, Engel W, Schmidtke J: A human Y-chromosomal DNA sequence expressed in testicular tissue. Nucleic Acids Res 1987, 15:8713-8724.

26. Holdenrieder S, Stieber P, Chan LY, Geiger S, Kremer A, Nagel D, Lo YM: Cell-free DNA in serum and plasma: comparison of ELISA and quantitative PCR. Clin Chem 2005, 51:1544-1546.

27. Zimmermann B, El-Sheikhah A, Nicolaides K, Holzgreve W, Hahn S: Optimized real-time quantitative PCR measurement of male fetal DNA in maternal plasma. Clin Chem 2005, 51:1598-1604.

28. Lo YM, Lau TK, Chan LY, Leung TN, Chang AM: Quantitative analysis of the bidirectional fetomaternal transfer of nucleated cells and plasma DNA. Clin Chem 2000, 46:1301-1309. 
29. Yan Z, Aydelotte T, Gadi VK, Guthrie KA, Nelson JL: Acquisition of the rheumatoid arthritis HLA shared epitope through microchimerism. Arthritis Rheum 2011, 63:640-644.

30. Yan Z, Lambert NC, Ostensen M, Adams KM, Guthrie KA, Nelson JL: Prospective study of fetal DNA in serum and disease activity during pregnancy in women with inflammatory arthritis. Arthritis Rheum 2006, 54:2069-2073.

31. Yan Z, Lambert NC, Guthrie KA, Porter AJ, Loubiere LS, Madeleine MM, Stevens AM, Hermes HM, Nelson JL: Male microchimerism in women without sons: quantitative assessment and correlation with pregnancy history. Am J Med 2005, 118:899-906.

32. Atkins CJ, Chan WFN, Naismith D, van der Westhuizen N, Woo J, Cortez V: The Clinical Features of 13 Women with Microchimerism in Rheumatoid Nodules. Arthritis Rheum 2010, 62(Suppl 10):1060.

33. Johnson KL, McAlindon TE, Mulcahy E, Bianchi DW: Microchimerism in a female patient with systemic lupus erythematosus. Arthritis Rheum 2001, 44:2107-2111.

34. Hromadnikova I, Zlacka D, Hien Nguyen TT, Sedlackova L, Zejskova L, Sosna A: Fetal cells of mesenchymal origin in cultures derived from synovial tissue and skin of patients with rheumatoid arthritis. Joint Bone Spine 2008, 75:563-566.

35. Mosca M, Curcio M, Lapi S, Valentini G, D'Angelo S, Rizzo G, Bombardieri S: Correlations of $Y$ chromosome microchimerism with disease activity in patients with SLE: analysis of preliminary data. Ann Rheum Dis 2003, 62:651-654

36. Kremer Hovinga IC, Koopmans M, Baelde HJ, de Heer E, Bruijn JA, Bajema IM: Tissue chimerism in systemic lupus erythematosus is related to injury. Ann Rheum Dis 2007, 66:1568-1573.

37. Kremer Hovinga IC, Koopmans M, Baelde HJ, van der Wal AM, Sijpkens YW, de Heer E, Bruijn JA, Bajema IM: Chimerism occurs twice as often in lupus nephritis as in normal kidneys. Arthritis Rheum 2006, 54:2944-2950.

38. Khosrotehrani K, Johnson KL, Lau J, Dupuy A, Cha DH, Bianchi DW: The influence of fetal loss on the presence of fetal cell microchimerism: a systematic review. Arthritis Rheum 2003, 48:3237-3241.

39. Petz LD: Bone Marrow Transplantation. In Clinical practice of transfusion medicine. 3rd edition. Edited by Petz LD, Swisher SN, Kleinman SN, Spencer RP, Strauss RG. New York: Churchill-Livingstone; 1996:772-776.

40. Kremer Hovinga IC, Koopmans M, de Heer E, Bruijn JA, Bajema IM: Chimerism in systemic lupus erythematosus-three hypotheses. Rheumatology (Oxford) 2007, 46:200-208.

doi:10.1186/1471-2474-14-325

Cite this article as: Kekow et al.: Long-term persistence and effects of fetal microchimerisms on disease onset and status in a cohort of women with rheumatoid arthritis and systemic lupus erythematosus. BMC Musculoskeletal Disorders 2013 14:325.

\section{Submit your next manuscript to BioMed Central and take full advantage of:}

- Convenient online submission

- Thorough peer review

- No space constraints or color figure charges

- Immediate publication on acceptance

- Inclusion in PubMed, CAS, Scopus and Google Scholar

- Research which is freely available for redistribution 